\title{
COMMENT
}

\section{Food of the dogs}

\author{
Gregory A Petsko*
}

Once again, while Greg is slacking off on vacation, his two dogs, Mink and Clifford, nobly pitch in to keep his column going. For those of you who have not met them previously (they are semi-regulars to these pages), Mink is a brave, loyal, intelligent chocolate Labrador retriever whose duties include guarding the house and watching over the family by testing all food to make sure it's safe to eat. Clifford, a small mixed poodle/spaniel, seems primarily to have the job of chasing tennis balls. As usual, their column takes the form of an imaginary dialog, much like those invented by Plato between Socrates and Glaucon. Of course, it's also possible that Plato borrowed the literary device from Mink and Clifford. Classical scholars are still debating this point.

Editor

Mink (reading aloud): "It was the best of times, it was the worst of times."

Clifford: Well, which was it?

Mink (ignoring him): "It was the age of wisdom, it was the age of foolishness."

Clifford: For Pete's sake, make up your mind!

Mink (sighing): I'm just reading you the opening of Charles Dickens's novel $A$ Tale of Two Cities.

Clifford: It seems to me this guy Dickens really likes to cover his -

Mink (quickly): Never mind. Greg suggested I might start with that quotation because he thinks the subject of our column this month is one more piece of evidence that we are living in the age of foolishness. I want to discuss the matter of Paleofood.

Clifford (who wasn't paying much attention until hearing the word "food"): Pail of food? I'd love a pail of food! What kind of food is in it?

Mink: Not pail of food, Paleofood. It's an increasingly popular food movement.

Clifford: If the food is still moving, we can just jump on it and -

*Correspondence: petsko@brandeis.edu

Rosenstiel Basic Medical Sciences Research Center, Brandeis University, Waltham, MA 02454-9110, USA
Mink: No. Let me explain. Another name for Paleofood is the Paleolithic diet; it's sometimes called the Stone Age diet or the Caveman diet.

Clifford: Like the Atkins diet that Greg tried once? [1] I see. You mean there are other kinds?

Mink: Oh, there are a great many. Humans are constantly experimenting with their diet. About 12 million people in the United States are vegetarian, which means that they don't eat meat.

Clifford: Don't eat meat! ARE THEY CRAZY?

Mink: I know. Amazing, isn't it? But there are also subgroups: ovo vegetarians, who include eggs in their diet but not dairy products, and lacto vegetarians, who include dairy products but not eggs.

Clifford: They should make up their minds. They sound like your friend Dickens.

Mink: I'm sorry I brought him up. You know, there are several other types of vegetarians too, but you get the idea. Then there are the vegans.

Clifford: Vegans? That sounds like they're from another planet.

Mink: They EAT like they're from another planet. They don't eat meat, dairy products or eggs. They only eat fruits, grains and vegetables.

Clifford: Like rabbits? I can't believe it; no meat or cheese or -.

Mink: I know. No dog would even dream of such a thing. Nevertheless, about $0.5 \%$ of the population in both the US and Great Britain are believed to be vegans. But the Paleolithic diet is very different. People on that diet eat a lot of meat.

Clifford: That's more like it. Why do they call it the Paleolithic diet?

Mink: The name was coined by a man named Walter Voegtlin, and the idea goes back to a book he wrote in the mid-1970s, although the diet has become more popular lately. It's based on the hypothesis that human physiology is not adapted to the things that were introduced into their diet after the Paleolithic era ended, which was about 10,000 years ago. That's when agriculture is supposed to have started. People on the Stone Age diet only eat Paleofoods, which are foods that the cavemen supposedly ate. Meats, fish, vegetables, fruit, roots, and nuts are OK, but the diet excludes grains, legumes, dairy products, salt, refined sugar, and processed oils. 


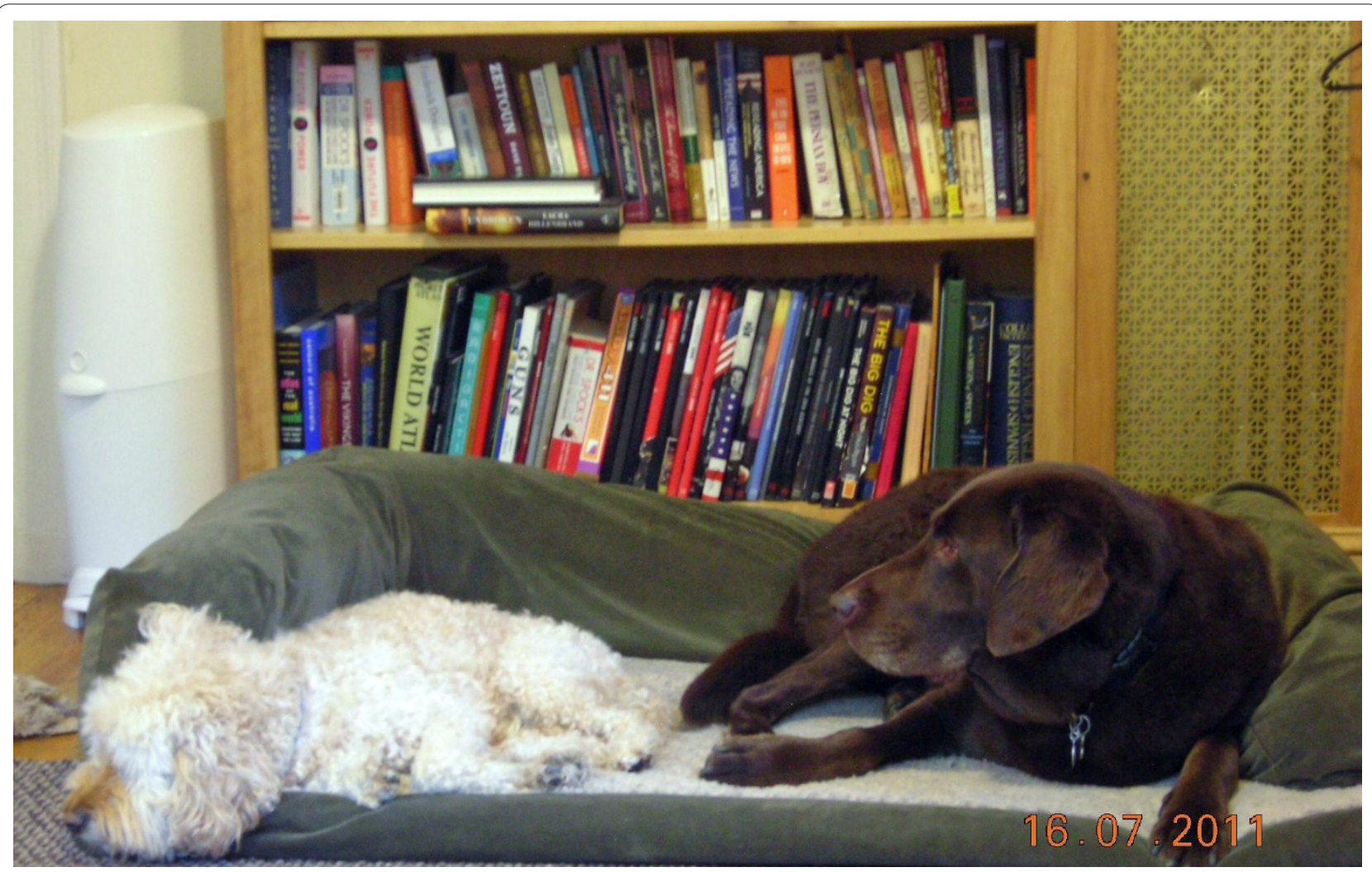

Figure 1. "Speaking of food, did someone just say it was suppertime?"

Clifford: How'd they figure out that those were the things prehysteric people -

Mink: Prehistoric people.

Clifford: If I got put on any of these modern diets, I'd be hysteric. Anyway, how'd they figure out what cavemen ate?

Mink: That's a really good question, and it's one of the biggest problems with that diet. There's some archaeological evidence, I think: garbage pits, cave paintings of hunting - that sort of thing. But a lot of it is just subtraction: they take what foods are available today, and subtract anything that they believe people started eating when agriculture came along.

Clifford: They assume that what's left is the Stone Age diet?

Mink: Basically. But the point is, they don't really know what cavemen ate. For example, there's some evidence for cereals in the diet as long as 100,000 years ago. And if you really want to go back to a primitive diet, well, how far back should you go? Most jungle apes don't eat meat, fish or vegetables; they typically eat only fruit. And then there's the Neanderthals.

Clifford: Is that a breed of dog, like Newfinlanders?

Mink: No, but it does sound like one, I admit. They are a type of humanoid who diverged from the line leading to modern humans about 500,000 years ago, and coexisted with them up to about 30,000 years ago - so they are
Paleolithic, but not the same as Homo sapiens. Their genome is about $99.5 \%$ identical to that of modern man, and its sequence suggests that many of them were lactose intolerant, a condition that affects about 50 million people in the US today.

Clifford: What does lactose intolerant mean?

Mink: It means they could not digest milk as adults.

Clifford: So they had a problem with what some people call a Neolithic food before Neolithic times?

Mink: Exactly. Lactose intolerance didn't arise because humans had trouble adapting to dairy products; it's much older than that. This shows that the history of human genetic adaptation to diet is a complicated subject and may not be easy to figure out from looking at human physiology today. Then there's also the question of the rate of evolutionary change.

Clifford: I thought you said the Paleofood diet was based on the idea that humans hadn't evolved to cope with agricultural food.

Mink: That's right. The claim is that 10,000 years isn't enough time for the genome to change in response to a drastic change in diet. There are several problems with that, I think. One of them is that it's not clear that the human genome - and maybe any other genome - really does change in response to diet if the effects of diet don't drastically affect reproductive fitness. Just because new 
food wasn't in the diet previously doesn't make it bad, and neither does the fact that an organism might not have been 'adapted' to that food previously. But the biggest problem is that 10,000 years is actually pretty long in terms of human generations, and it's not at all clear that evolutionary pressure can't operate on that time scale. In fact, lactose intolerance may be a good example that it can. There's pretty good evidence that the frequency of genetic alleles for lactose tolerance increased in the $H$. sapiens population in northern Europe within the last 10,000 years; the Neanderthals died out before the invention of agriculture, so their population didn't undergo that change.

Clifford: Is there any other evidence that humans might still be evolving fast, like dogs clearly do?

Mink: There might be. In some recent work, Xin Yi and colleagues sequenced 50 whole exomes - the $3 \%$ of the human genome in which known coding genes lie - of people of Tibetan ancestry, and compared them with the exomes of 40 Han Chinese. They estimate that Han and Tibetans diverged 2,750 years ago and experienced subsequent migration, the Tibetans spending most of the last 2,000 years living at high altitude - above 13,000 feet, where the oxygen content in the air is almost half what it is at sea level. They found that at least 30 genes were significantly different, and many of them code for proteins that are involved with oxygen utilization. For example, a change in the hypoxia-inducible factor 2-alpha, or $H I F 2 a$, gene was found with a frequency of $87 \%$ in Tibetans and 9\% in Han Chinese, and the Tibetans with the favored version have fewer red blood cells and hence less hemoglobin in their blood. When humans who have not adapted go to high altitudes, their blood thickens as the body tries to counteract the low oxygen levels by producing more red blood cells. This overproduction of red blood cells leads to altitude sickness and to lesser fertility - Han Chinese living in Tibet have three times the infant mortality of Tibetans. So you can see that this particular genetic change could clearly be under selective pressure. In fact, this polymorphism may have experienced a faster rate of frequency change than the lactose tolerance allele in northern Europe. And even if the actual divergence date of Tibetans from Han Chinese is, say, 6,000 years ago instead of about 3,000, these data still suggest that humans can experience adaptive changes pretty fast [2].

Clifford: So the thinking behind the Paleolithic diet is questionable, to say the least? OK, I see that, but what about the diet itself?

Mink: Well, what do you think about humans eating only meat, nuts, roots, vegetables, fish and fruits?

Clifford (trotting over to a large bag of dry dog food and reading the label): "Beef, sweet potatoes, apples, carrots - " Greg buys this limited ingredient food for me because I have a skin allergy to some grains. This sounds just like the Paleolithic diet.

Mink: It sure does. Interesting, isn't it? The perfect meal for people on that diet is premium dog food.

Clifford: Well, they can't have mine! Still, it sounds like they should call it the Puppyolithic diet.

Mink: Or the Cavedog diet.

Clifford: I don't understand humans sometimes.

Mink: Sometimes?

Clifford: OK, lots of times. But especially this time. Why don't people who have no specific food allergies just eat a balanced diet in sensible quantities?

Mink: I don't know. But humans have always been peculiar when it comes to food. John Harvey Kellogg, who invented corn flakes, ran a kind of hospital in which he pumped yoghurt into his patients, not only through their mouths, but also - well, let's just say he believed in coming at the diet problem from more than one direction. The grapefruit diet, which started around 1930 and is also known as the Hollywood diet, consisted of eating half a grapefruit with every meal and reducing the total number of calories to below 800 a day, which can be dangerous for some people. Then there was the Gerson diet, which was supposed to cure cancer (the National Cancer Institute says it doesn't). Dating back to the 1920s, this diet tried to reduce sodium levels in the body and increase potassium levels, and some people on it actually died from an imbalance in their electrolytes. Yet the diet is still being used, here and in Australia. In the US especially, people are forever trying some new fad diet. The Caveman diet is just the latest in a long line of silliness.

Clifford: Are they loopy about food in England too?

Mink: Not as much. They're loopy about animals.

Clifford: That at least makes sense. Sounds to me, though, like this constant fascination with these weird diets is another sign that many people are just not very well-educated about science and are easily misled by pseudo-science.

Mink (nodding): That's part of it. Another part is that humans want to believe that things can come easily: good health should just be a matter of taking a pill, or following some strange diet. Never mind that so much of health depends on your genetic heritage, and on lifestyle issues like exercise, whether you smoke cigarettes and so forth.

Clifford: Do you think the Paleofood movement might also mean that a lot of humans are uneasy about modern life and long to go back to a time they believe is simpler and safer - even if that means going all the way back to the Stone Age?

Mink: Yes, I think you may be right about that. There is a persistent distrust of technology, coupled with anxiety about the future. Anyway, the end result is that, despite the enormous advances in science of the past 50 years, 
superstition and quackery still abound. Just like Dickens wrote, "It was the epoch of belief, it was the epoch of incredulity; it was the season of Light, it was the season of Darkness."

Clifford: Not again! What do you see in him? I don't think I've ever known anybody so confused in my entire life.

Mink (looking at Clifford, not unkindly): I have.

Published: 25 July 2011

\section{References}

1. Petsko GA: Live and let diet. Genome Bio/ 2003, 5:101.

2. Yi X, Liang $Y$, Huerta-Sanchez $E$, Jin $X$, Cuo ZX, Pool JE, Xu X, Jiang $H$, Vinckenbosch N, Korneliussen TS, Zheng H, Liu T, He W, Li K, Luo R, Nie X, Wu H, Zhao M, Cao H, Zou J, Shan Y, Li S, Yang Q, Asan, Ni P, Tian G, Xu J, Liu X, Jiang T, Wu R, et al:: Sequencing of 50 human exomes reveals adaptation to high altitude. Science 2010, 329:75-78.

doi:10.1186/gb-2011-12-7-122

Cite this article as: Petsko GA: Food of the dogs. Genome Biology 2011, 12:122. 